\title{
7 \\ The Land parliaments deputies in Germany
}

\section{Introduction}

When one reads of European parliaments and their members, one normally thinks of the national level. This is understandable with respect to the mostly unitary political systems, which have only national parliaments. But some of these states, such as Germany, Switzerland, Austria, and Belgium, are federal systems, and some others, such as Spain, have a semifederal territorial organization. In these systems far more parliamentarians are members of regional parliaments than of the national parliament. Nevertheless, since the regional parliamentarians receive much less media coverage and relatively little public attention in general, less is known about them than about their counterparts in the national capital. In Germany there is some newspaper coverage of the Land parliaments and their members, but very little attention is paid them by television. On certain occasions there may be a development or incident in a parliament which receives considerable public attention, but in general politicians at the Land level are not in the public eye and are not all that well known. Nevertheless, one issue that has been discussed to some extent by the attentive public is legislative salary and various benefits along with the question of whether the Land politicians are overpaid and underworked.

\section{The deputies: who they are}

As of summer 2002 there were 1916 Land deputies in the thirteen territorial states and three city-states, ranging in number from fifty-one in the smallest territorial state, the Saarland, to 231 in the largest territorial state, North-Rhine Westphalia. The Christian Democrats (in Bavaria, the CSU) 
had the largest overall number, 815 , while the SPD had 719. Among the small parties, the Greens had 107, the FDP ninety-three, the PDS 148, and others thirty-four. The Greens were represented in every West German Land parliament except for the Saarland, whereas in the new eastern Länder they had no seats except in Berlin. The FDP had representation in nine Länder, but in only one of the new Länder, and the PDS was confined to the five new Länder and Berlin. On the far right, the Republicans lost their last seats in Baden-Württemberg in 2001, but the German People's Union (DVU) had five seats in Brandenburg, and one in Bremen (Bremerhaven). The DVU lost all of its sixteen seats in Saxony-Anhalt in April 2002.

Each of the Land parliaments publishes a handbook with brief biographies and statistics about the deputies, including occupational and other data. Unfortunately, the organization of the data and categories are not standardized, and some of the handbooks provide more information than others. Indeed, some of the biographical information on occupational background is very limited. In 1994 Werner Patzelt sent a questionnaire to the 2,800 European, federal, and Land parliament deputies, about one-third of whom responded. ${ }^{1}$ Of the respondents, 639 were Land deputies. The largest single group (21.6 percent) consisted of teachers, and all public employees together accounted for 45.3 percent of the deputies. The next largest group (15.4 percent) were employees in industry and trade. However, data collected by the author on deputies in the East show that a high proportion are or were employed in state-owned industry and trade firms and that many are or were engineers of various kinds. Different kinds of teachers also made up a significant proportion of the Eastern deputies, but otherwise public employees are a much smaller proportion of parliaments in the East than in the West (Table 7.1).

Patzelt found relatively few deputies who said they were still practicing their occupations on a full-time basis; indeed, on a five-point scale, about 70 percent selected points 4 or 5 , i.e., they were engaged in their occupations very little or not at all. A sizable plurality of 44.5 percent considered themselves to be in the middle of a five-point scale on social class background. The average age was early fifties, and three-fourths of the deputies were male. A little more than 28 percent said they had served more than twelve years in office (20.4 percent said seven-twelve years). ${ }^{2}$

Based on the statistics collected by the author for half of the Länder, the proportion of women in the Land parliaments ranged from 21 percent in Bavaria to 39 percent in Bremen. The Greens consistently have the largest proportion of women (40-57 percent), the Christian Democrats the smallest (11-32 percent). The average age of the deputies is between 
Table 7.1 Parliamentary seats in the Länder, 1998-2001

\begin{tabular}{lrrrrrrr}
\hline & Total & & & & & & \\
Land (Year of Last Election) & seats & SPD & CDU & FDP & Greens & PDS & Other \\
\hline Baden-Württemberg (3/2001) & 128 & 45 & 63 & 10 & 10 & - & - \\
Bavaria (9/1998) & 204 & 67 & $123^{\mathrm{a}}$ & - & 14 & - & - \\
Berlin (10/2001) & 141 & 44 & 35 & 15 & 14 & 33 & - \\
Brandenburg (9/1999) & 89 & 37 & 25 & - & - & 22 & $5^{\mathrm{b}}$ \\
Bremen (6/1999) & 100 & 47 & 42 & - & 10 & - & $1^{\mathrm{b}}$ \\
Hamburg (9/2001) & 121 & 46 & 33 & 6 & 11 & - & $25^{\mathrm{c}}$ \\
Hesse (7/1999) & 110 & 46 & 50 & 6 & 8 & - & - \\
Lower Saxony (3/1998) & 157 & 83 & 62 & - & 12 & - & - \\
Mecklenburg-Vorpommern (9/1998) & 71 & 27 & 24 & - & - & 20 & - \\
North-Rhine Westphalia (5/2000) & 231 & 102 & 88 & 24 & 17 & - & - \\
Rhineland-Palatinate (3/2001) & 101 & 49 & 38 & 8 & 6 & - & - \\
Saarland (9/1999) & 51 & 25 & 26 & - & - & - & - \\
Saxony (9/1999) & 120 & 14 & 76 & - & - & 30 & - \\
Saxony-Anhalt (4/2002) & 115 & 25 & 48 & 17 & - & 25 & - \\
Schleswig-Holstein (2/2000) & 89 & 41 & 33 & 7 & 5 & - & $3^{\text {d }}$ \\
Thuringia (9/1999) & 88 & 21 & 49 & - & - & 18 & - \\
& & & & & & & \\
Total & 1916 & 719 & 815 & 93 & 107 & 148 & 34 \\
\hline
\end{tabular}

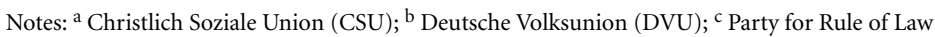
Offensive (PRO); ${ }^{\mathrm{d}}$ Südschleswigscher Wählerverband (SSW).

Sources: Wahlergebnisse in Deutschland, 1946-1998 (Mannheim: Forschungsgruppe Wahlen, 1998); Karl-Rudolf Korte, Wahlen in der Bundesrepublik Deutschland (Bonn: Bundeszentrale für politische Bildung, 1998); www.wahlrecht.de/landtage with links.

forty-five and fifty. The Greens generally have the lowest average age, while the CDU and SPD are about the same.

Based again on data from about half of the Länder, a number of generalizations can clearly be made. In terms of occupation, a large majority of the delegations of the SPD and Greens are white-collar employees. Some of the SPD deputies are from the private sector, but relatively few Greens have worked for private employers. A large proportion of SPD and Green deputies, and a smaller but still sizable proportion of CDU deputies, have positions in the public service. Most of these are Beamte, i.e., persons holding positions in the public sector with some degree of responsibility at the Land and local levels. It is often asserted that most of the Beamte are school teachers and others involved in education, but the data suggest that this group is generally a sizable minority of the public employees who are deputies and from 5 to 30 percent of the total party delegation, depending both on the party and the Land. The SPD has from one to five union employees in its delegations, and both of the large parties and the 
Greens often have employees of local public enterprises in their party groups. Frequently these three parties also have one or more political party employees in their delegations. The important point is that most deputies are economically dependent employees. This has consequences for compensation practices, which are said to reflect the lack of financial independence of the deputies. On the other hand, public employees are guaranteed the right to return to their positions, for example, as teachers, if and when they leave the parliament before retirement age.

A minority of deputies are self-employed. Lawyers are fairly well represented, though they constitute a small minority of the total and are a far less important occupational group than in many US legislative bodies. Housewives and an occasional househusband are represented in small numbers, and a few students are deputies, especially in some Green delegations. Retirees are small in number.

\section{The deputies: what they do}

In the early 1990s an intensive study was made of the deputies of the parliament of Lower Saxony. On the basis of personal observation of plenary meetings, committee meetings, party groups and their specialized subject working groups; lengthy interviews and discussions with deputies and staff; accompanying selected deputies during one week's activities; a questionnaire focusing on time spent on various activities during a particular month; and visits to constituencies with deputies, a comprehensive picture was developed of the activities of the then 155 deputies in Hanover. ${ }^{3}$ One result of the study was that the average work week for deputies was 76.7 hours, which conforms with the results of studies done earlier in Baden-Württemberg and Schleswig-Holstein. ${ }^{4}$ Excluding the hours worked in occupations in which some deputies were still engaged, the average number of hours in the workweek of a deputy was 62.1 . The differences among party groups in hours worked in various occupations outside of parliament were significant: CDU deputies worked on average 15.9 hours; FDP 13.3 hours; and the SPD 10.4 hours. None of the Greens worked at another occupation while they were deputies. The range in the workweek as deputies was between 49.7 and 103 hours. There were minor differences between men and women, party leaders and backbenchers, newcomers and veterans, and those directly elected and those elected over the party lists. There were also few differences between deputies of the large parties, SPD and CDU, at 77.4 and 75.4 hours, respectively, while the 
much smaller FDP and Green delegations claimed to put in 81.2 and 83.9 hours, respectively. This was due in large part to the extra demands placed on their smaller numbers. ${ }^{5}$

Another important and even more thorough academic study, based on interviews in Bavaria in 1989 of representatives in the Land, federal, and European parliaments, was published in 1993. A second book by the same author, based on the same data but organized differently and designed more for the general reader, appeared in 1995. ${ }^{6}$ The author, Werner Patzelt, concluded that Land deputies worked on average about 60 hours per week. ${ }^{7}$ A third study, conducted by the same author in 1994 was based on the results of a mailed questionnaire of 2,800 deputies at the European, federal, and Land levels. ${ }^{8}$ During the weeks when parliament met, which in most cases included committee meetings, the respondents from the federal and Land levels put in about 65 hours on average, excluding travel time, work in other occupations, etc. During weeks when the parliament did not meet and the focus was on the home district, the average was about 54 hours. According to the respondents, about one-half of their total working time was spent on parliamentary matters, about one-third on district activities and service. ${ }^{9}$ Even if one is skeptical of the claims of some of the deputies, there can be little doubt that most of them have a very long work week.

What do they do that takes up so much time? There are three sets of activities in which all of the deputies engage: activities related directly to parliamentary work; activities in the election district, even if elected over the party list; and activities related to their political party. A fourth set of activities which takes up a good deal of time of most deputies is connected with an elected office at the municipal and/or county level.

\section{Parliamentary work}

With respect to parliamentary work, the deputies attend party group meetings and meetings of specialized party working groups in which party initiatives and positions related to their committee assignments are discussed and occasional trips are made to places within the Land to gather information and make contacts; these make up the core of parliamentary activity for the deputies, and it is in the working groups that they spend the most time, including reading and preparation. All deputies participate in committee meetings, which, depending on the committee, meet normally from once to seven or eight times a month. In contrast to other Länder that have special petition committees, the committees in Lower Saxony receive 
complaints, concerns, and inquiries from citizens that are related to the subject matter of the committees. These communications are checked first by parliamentary administrative staff who then direct them to the appropriate committees for action. Of course the activity most familiar to the general public is the plenary meeting of parliament; however, full meetings take place only for three successive days every month except in late summer for a total of about thirty days during the year. They can be timeconsuming for party leaders and those who are making prepared speeches, but even these are seen as largely staking out party positions for public consumption, especially for the press, and for gaining some publicity back home. The plenary sessions are especially tedious for the Opposition deputies, who can achieve few concrete results against the majority party or coalition. The tendency to raise a large number of rather minor questions during question time is also time-consuming and tedious. Few deputies are willing to sit for any length of time through the speeches, questions and routine actions that do not interest or concern them directly, especially when they have many other things they would rather be doing. But from the gallery, of course, the public sees many empty seats, not the delegates who are actually meeting and talking with constituents, other deputies, interest groups, and others outside in the hallways or lobby. ${ }^{10}$ The belief by the general public that the work of their deputies is or should be done in the legislative chambers is also a problem in the United States, where disappointed citizens often see from the visitors' gallery mostly empty seats and a few inattentive legislators. ${ }^{11}$

In contrast to the public view, legislators themselves see the plenary meetings as relatively unimportant. When asked to indicate the importance of various parliamentary activities, 95 percent of the respondents in Patzelt's 1994 study said committee meetings were important, 92 percent pointed to party group meetings, 91 percent listed specialized party working groups, and only 50 percent said plenary meetings were important. Seventy percent thought that informal contacts with members of their own party were important, 43 percent thought the same about contacts with members of coalition parties, and only 25 percent felt that contact with Opposition members were important; 57 percent thought contacts with journalists were important. ${ }^{12}$

\section{District work}

The second set of activities, which deputies see as crucial for reelection purposes, is their work in the district. ${ }^{13}$ This consists of contacts with local 
citizens, local administrative offices, local businesses, groups of all kinds, and, of course, the local press. This work is not only a process of meeting people and remaining in contact; it also involves an ombudsman function, ${ }^{14}$ including telephone calls at virtually all times of the day. These activities take up an average of one-third of the working time for the week. (In the study in Bavaria about 37 percent of the deputies suggested that more than 50 percent of the total time they spent on political work was connected with their districts. ${ }^{15}$ ) Not only do the deputies hear the wishes and concerns of their constituents; they also have an opportunity to express their views and the position of their party on relevant issues. Thus the deputy serves as the "transmission belt" between the district and the state capitol, possibly even assisting in gaining grants for local projects - although that is unlikely for an Opposition deputy. A common strategy is membership in or close contact with various local groups, for example, attendance at two or three functions or meetings every week and meeting with local politicians. One of the most damaging accusations against a deputy is that he or she is "distant" and "absent" or unconcerned about district voters and their views and wishes, and therefore deputies feel obligated to accept virtually every invitation to attend the various functions in their district. A study of deputies in the five new Länder, however, has shown that they were spending far more time on legislative than district activities in comparison to their counterparts in the West, at least in part due to the need to pass large amounts of legislation that had been passed in the western parliaments over several decades. On the other hand, the PDS, which, given its opposition status, carried much less parliamentary responsibility for this legislation, was focusing more attention on district work. ${ }^{16}$

Still, there are party differences among the deputies, e.g., the deputies from the small parties are generally unable to spend as much time in the district as their large party counterparts, and the Green deputies are less concerned with local "lobbying" activities for ideological reasons. The study in Lower Saxony also found differences between the governing party, SPD, and the Opposition CDU deputies, who were somewhat more likely to concentrate on district work than on parliamentary activities for the obvious reason that most of their parliamentary work was for naught. On the other hand, there were significant differences in approach to district work within both large parties. ${ }^{17}$

Deputies maintain contacts with the district population not only through attendance at various functions but also through personal communication. Telephone calls to the homes of deputies are common, 
including on Sundays. Some deputies hold office hours in the district as a service to their constituents. A majority of deputies in the Lower Saxon study, however, did not, arguing in part that their experience showed that many constituents felt uncomfortable about going to an office to discuss their concerns and preferred individual contact, including home visits. On average deputies made two or three such visits each week. ${ }^{18}$

Given the amount of time deputies at all levels devote to their districts, it is not surprising that most of the responding deputies (53 percent) in Patzelt's 1994 study believed their views reflect those of their constituents, while only 6 percent were doubtful. ${ }^{19}$ Unfortunately, polling data have suggested that only 23 percent of the population believed Land deputies are well informed about the views of their constituents, and 35 percent assumed they are poorly informed. Only 13 percent said it is easy to meet with a deputy, and 21 percent even thought it was nearly impossible. ${ }^{20}$ Needless to say, these are depressing figures for deputies who put so much effort into making and maintaining contacts at home.

While 39 percent of the deputies thought citizens in their districts would give them good grades for their work, 8 percent suspected they would get bad grades; however, 70 percent thought they would be graded favorably by the politically interested citizens. Most felt their constituents had positive views about them individually, but they recognized that citizens generally had negative assessments of parliament as a body, which 76 percent said they found troubling (belastend). ${ }^{21}$ The contrast in the public views regarding their individual representative on the one hand and the legislature as an institution on the other is also well known in the United States, where polls commony indicate that citizens like their own congressman but are contemptuous of Congress.

\section{Political party work}

A majority of Land deputies hold one or more offices in their political parties at the local, regional and/or Land level. Party work is essential for several reasons. There must be contact and cooperation between the extra-parliamentary party and parliamentary party group. For example, the deputy reports in local party meetings on developments in the parliament and receives feedback from the regular members. Holding party office helps to integrate the deputy into the party organization and maintain contact with local party leaders. This is another means by which the deputy serves as a "transmission belt" between local party members and the parliamentary party group. Party office also increases the deputy's 
influence over party policies and personnel matters. Finally, party office is an important means of retaining support for renomination as the party's candidate for the next election. Holding a party office and simultaneously serving in the Land parliament can lead to a variety of tensions, from complaints about party policy at the Land and federal levels for which the deputy is supposed to answer to envy from others in the party with whom the deputy has had a close relationship in the past. ${ }^{22}$

\section{Local council offices}

For the typical deputy, the list of activities does not end with parliamentary, district, and party work, but is complemented by office holding in local councils at the municipal or county level and, not infrequently, at both local levels. The practice of holding multiple offices is probably best known in France, where, in order to secure their local political base, deputies in the National Assembly and even ministers are often mayors or important officials in their communes. While members of the Bundestag rarely hold multiple offices, it is a common practice for Land deputies. This is because deputies usually serve at the local level before being nominated as a candidate for the Land level, and local office helps to provide the deputy with a political base in the home district; second, it is an important means of keeping the deputy in touch with the problems and concerns of local governments, which are an important responsibility of the Land parliaments. According to the personal bibliographies in the Handbook of the Lower Saxon parliament, 73 percent of the SPD and 60 percent of the CDU deputies served in a municipal council in the mid1990s, while the percentage serving in county councils was 41 and 51 percent, respectively. Some had served in the past, but not while they were members of parliament. In some American state legislatures, a majority of the legislators may also have held a local government or party office, while in others the proportion with previous experience may be considerably less; ${ }^{23}$ in any case they are not allowed to hold a local government office while they are members of the legislature.

In addition to the activities described above, most deputies are also members of various private and public boards, including charitable organizations; committees; and organizations, for example, local public savings and loan associations and public enterprises. Particularly from an American perspective, it is interesting that 4.5 percent of the CDU, 59 percent of the SPD, and 31 percent of the Green deputies in Lower Saxony were members of unions in the mid-1990s. Many of 
the SPD deputies were actively engaged in activities related to their union membership.

Taken together, the four general areas of activity of Land deputies require an inordinate amount of time, and it is not surprising that the deputies report an average workweek of over 60 hours excluding any time spent on activities not related to their work as office holders. But as with other professions, including academia, it is often difficult to explain the work load to outsiders who simply do not see the many obligations of deputies beyond their participation in plenary sessions, from which they absent themselves during much of the time when issues that do not interest or affect them are being discussed. This may be a problem that is common to legislators in all democratic societies. In Germany it is complicated by relatively high salaries and benefits, which can and do create considerable resentment and controversy.

\section{The deputies: what they earn}

The salaries and benefits of Land deputies are described in some detail in the "The Law Concerning Deputies" (Abgeordnetengesetz) contained in the respective Land parliamentary handbooks. The Law is divided into numerous sections, including "Compensation," "Reimbursement of Expenses," "Transition Payments," "Health Insurance," "Pensions," and so forth. Until the famous "compensation decision" (Diätenurteil) rendered by the Federal Constitutional Court in $1975,{ }^{24}$ most Land deputies were part-time with modest compensation packages. But the Court held that if deputies are full-time, they should be paid a full salary commensurate with the status and responsibilities of the office..$^{25}$ As a result the compensation for deputies in the Länder was increased dramatically. ${ }^{26}$ Even though the Court revised the Diätenurteil in 1987,27 the Land parliaments continued to increase compensation packages by significant amounts.

There are two parts to the compensation package received by the deputies. One part is literally "compensation" (Entschädigung), which includes base salary, transition pay, pension benefits, and assistance in meeting the costs of illness, births, and deaths. The other is the reimbursement of expenses (Aufwandsentschädigung), which is designed to cover office expenses, telephone and postage, travel and hotel expenses, public transportation, and office help. The legislative assembly of the city state of Hamburg used to be the exception to this two-part compensation package, since it perceived itself as a part-time body and provided only 
reimbursement of expense; ${ }^{28}$ however, it now has a two-part package in spite of its continued self-perception as a part-time assembly. ${ }^{29}$

The base salaries of the deputies vary considerably from Land to Land. Salaries in the sixteen Länder in the mid-1990s ranged from DM 4,457 in Bremen (under certain circumstances supplemented by reimbursements for absences from regular work) to DM 1,1266 in Hesse (figured at $\$ 1.00 / \mathrm{DM}=1.60$ - about the average exchange rate in the second half of the 1990 s - this is $\$ 7041$ per month!). The average in the old territorial states was DM 8,828 (\$5330), in the new territorial states DM 6,633 (\$4146). These are full-time salaries designed for full-time deputies, but some deputies, depending on the Land, do continue to work part-time as public employees or as self-employed persons in business or law. ${ }^{30}$

In addition to the base salary, Entschädigung includes transition money, i.e., full salary payments made to deputies who leave office for any reason, whether because of electoral defeat or voluntary departure for another job. Transition payments are made for one-three months to those who have served for as little as one year and for a maximum of twelve-thirty months for service of ten-twenty-two years. The total maximum payment could amount to DM 53,484 in Bremen to DM 214,500 (\$134,063) in Schleswig-Holstein. ${ }^{31}$ These payments have come under considerable attack, and they were reduced in recent years at the federal level.

A third major part of the Entschädigung consists of the retirement benefits. Lifetime retirement benefits amount to 25-35 percent of full salary for the minimum service of eight-ten years beginning at sixty years of age; these payments increase 3-5 percent each additional year of service to a maximum of 75 percent of salary beginning at age fifty-five in most Länder for long-time office holders (thirteen-twenty-three years). In four of the new Länder there are even provisions for modest pensions for deputies who served only one term in the first parliaments after unification. In addition to these very generous retirement benefits, deputies receive assistance for health care as well as birth and death payments. ${ }^{32}$

Ministers who still have their seats in the Land parliament receive a higher compensation; some even receive double payments, e.g., 50 percent of the deputy salary in addition to their ministers' salary in Bavaria, Berlin, North-Rhine Westphalia, and Saxony, and 70 percent in BadenWürttemberg. In the other territorial states the ministers receive 25-35 percent of the deputy salary. In Lower Saxony, however, there is no double payment, and in Bremen and Hamburg incompatibility rules prevent double office holding. Double payments also exist for pensions, e.g., full 
deputy pension plus one-half of a minister's pension. In Lower Saxony, again, only the higher of the two is paid. ${ }^{33}$

The second part of the total compensation package, as noted above, is reimbursement for expenses. This includes travel, hotel, and meals as well as free use of office space, government cars, telephones, and free public transportation. Two systems of payment are employed: lump sum and separate billing. The lump-sum payment is provided by Bavaria (DM 4711) and Berlin. Critics charge that some of this amounts to income, because payments are higher than actual expenses, especially for deputies who live near the capital, have no district offices, etc. The second system of payment is by separate billing for travel, hotel, and meals. The remaining range of partial lump sum payments for other expenses is from DM 769 in Bremen to DM 2,191 in North-Rhine Westphalia. According to two studies, these payments are also in excess of actual expenses. ${ }^{34}$ Ministers and state secretaries also receive partial lump-sum payments that can range from DM 500 in Lower Saxony to DM 3,533 in Bavaria. In some Länder ministers even receive a lump-sum payment as deputies in spite of their chauffeured cars and other amenities. ${ }^{35}$

Given the high degree of regulation in German society and the "flood of legislation" that is the focus of many complaints among German legislators, it is surprising that some areas that are rather closely regulated in the United States have been ignored in Germany. A good example is the lack of regulation of private donations to legislators. In contrast to donations to political parties, there is no requirement of publicity for donations to individual politicians who may use the money received in any manner they wish, although they are most likely to pass it on to their party for campaign purposes. The only requirement at the federal level is that the deputy inform the President of the Bundestag of any donation of DM 1,000 or more. For donations of DM 20,000 or more to a political party, the donor must be named; that provision applies to individual legislators as well, according to the new party finance law of 1992. Only in Lower Saxony and Bremen is it illegal for a deputy to be paid a retainer by his firm or serve as a consultant while in office. ${ }^{36}$

It is clear from the above why the compensation packages received by office holders in the Länder - and at the federal and EU levels - have been so controversial in recent years. ${ }^{37}$ And it certainly does not help when a report appears in the press about an SPD Land deputy from North-Rhine Westphalia who, in spite of a very generous salary and reimbursement package of about DM 12,000, was discovered to be receiving an additional DM 3,000 per month in unemployment 
compensation on the grounds that his regular job before he entered parliament had been eliminated! ${ }^{38}$

By international comparison, even politicians at the Land level in Germany are well paid. They are also very well paid in comparison with "professional," full-time American state legislators, e.g., in New York or California. ${ }^{39}$ But given the sixty-hour- plus weekly work loads of Land deputies, it can be argued they are not overpaid, especially when compared with high-salary employees in the private sector. This argument also applies to other Western democratic industrial societies, some of which, for example, Great Britain, pay their politicians far less than Germany. In fact, one reason why such a large proportion of the deputies are public and private employees, rather than more from the self-employed ranks as in the United States, is that the generous total compensation packages provide the office holders with higher incomes than they would receive in their regular positions, e.g., school teachers and other mid-level civil servants and private employees. This, together with the added prestige and social status - in spite of Politikverdrossenheit (alienation from or annoyance with politics) and the criticism directed toward the "political class" today in Germany - help explain why there is a tendency for office holders to cling to their positions. But this is a phenomenon observable among the more professionally oriented state legislators in the United States as well. ${ }^{40}$ It is possible for legislators in Germany who entered parliament from the public service to return to their old pre-legislative positions, a prospect most seem to find uninviting; however, there is little tradition of moving to a well-paid, relatively high-status position in the private sector as is common in the United States. German "professional politicians" are more likely than many of the more financially independent American state legislators to live "off" politics, and, one might argue, as a result a larger proportion of Germans from the broad middle class rather than the middle to upper middle class are recruited into the legislature.

While it is clear that deputies in Germany are well paid, it should also be pointed out that they have high expenses. Like American politicians, they are not only invited to speak at and attend many functions and group meetings in their districts; they are also expected to contribute to the cause in many cases. Sizable contributions are especially expected - and required - by the political parties. Rarely, if ever, is anyone elected who is not a member of a party. This membership is not merely nominal, as is usually the case in the United States. Rather, "card-carrying" membership is the norm, which means monthly dues ranging from a dozen or so DM per month to hundreds of DM in the SPD, which has a dues structure 
graduated by income. In the past deputies were expected to contribute sizable funds to their party groups, while today this practice is supposed to have been banned with the party groups being funded generously by the public treasury. Nevertheless, some funding by deputies continues. Above all the deputies are expected to provide the parties with monthly donations amounting to DM 1,000 (about 500 Euro) or more, often referred to as a "party tax." The Greens pay an especially high party tax. This "tax" can be seen as a hidden form of party financing, especially given the provisions of the tax law that give private citizens a 50 percent tax credit and the party a 50 percent bonus designed to encourage private donations. ${ }^{41}$ Deputies also give sizable amounts of money to their parties for election campaigns, since these are organized and fought by the parties, not by individual candidate organizations. One deputy told the author that he gives voluntarily about DM 20,000 to his party each year.

All in all, there is a considerable gulf between the often sharp criticisms of deputies and their salaries and benefits on the one hand and the views of the deputies themselves. Given the number of hours they devote to their work related directly and indirectly to parliamentary activities, to their districts and the services they perform, to the local government offices most of them occupy, and to their party activities, which are necessary both to maintain contact with supporters and retain the nomination for their seat in parliament, and the pressures these numerous and timeconsuming obligations place on their family and private lives, most deputies believe they earn too little rather than too much. ${ }^{42}$ Interviews which the author conducted with selected deputies in Lower Saxony also suggest they are resentful of charges that they are overpaid.

\section{The deputies: part-time, full-time, or what?}

In his influential essay, "Politics as a Profession," Max Weber distinguished among three kinds of elected office holders: the professional, the part-time, and the occasional politician. ${ }^{43}$ Professionals can be distinguished further between those who live "off" of politics and those who live "for" politics. The former are dependent on the salaries they receive as office holders, the latter have independent sources of income.

In the United States, relatively high salaries, length of session, and staff support are the three variables that determine the degree of "professionalization." Most state delegates have traditionally been part-time politicians; however, in recent decades professional politicians have come to dominate 
the legislatures of at least nine states, with New York and California in the lead. Most of the legislators in these nine states with "professional legislatures" are full-time and live "off" politics, although some of the more affluent delegates live "for" politics. The salary range of these legislatures in 1997-98 was between $\$ 75,600$ in California (raised to $\$ 99,000$ in January 1999) and $\$ 35,000$ in New Jersey, and the average annual duration of the legislative session in 1996-97 ranged from 365 calendar days in Wisconsin to 133 in Illinois. Legislative staff ranged from 3,899 in New York to 552 in Ohio. At the other end of the continuum, the legislatures in about sixteen American states can be categorized as "citizen" legislatures, with salaries ranging from $\$ 15,000$ in West Virginia to \$200 in New Hampshire, which also has the largest state legislative body with 400 delegates. Needless to say, few legislators in these states could live "off" politics, but not all of them are part-time. While the average annual duration of the session in 1996-97 was, as one would expect, shorter than for the professional legislatures, the range was from thirty-six days in Wyoming to 256 days in Rhode Island, which pays its legislators only $\$ 10,250$. Staff support in these legislatures ranged from 742 in Georgia to fifty-eight in Vermont. The legislatures in about twenty-five states in between these two extremes are categorized as "hybrid," with salaries ranging from $\$ 32,000$ in Hawaii to $\$ 1,040$ in Alabama and an average annual duration of session ranging from 177 days in Delaware to fifty-two in Kentucky. ${ }^{44}$ Staff support in the hybrid state legislatures ranged from 2,420 in Texas to 164 in Delaware. Most of the delegates in these hybrid states probably live "for" politics; nevertheless, many of them in both the citizen and hybrid legislatures, and particularly those with major responsibilities such as speakers, committee chairs, and party caucus leaders, are really full-time politicians. ${ }^{45}$

In Germany most Land deputies are full-time professionals who live "off" politics. The exception is perhaps the Hamburg assembly, which in law, if not in practice, ${ }^{46}$ is part-time. The change from part-time to fulltime professional took place after a Federal Constitutional Court decision in 1975 suggested - but did not require, as some Land deputies seemed to think ${ }^{47}$ - that they should receive a full-time salary commensurate with their responsibilities. This has always been a controversial decision, because it served as the basis for very generous salary levels and benefits for Land deputies that approach or, in a few cases, are even roughly comparable to federal-level salaries. Some critics believe the compensation packages are not only unjustified; they are also the result of a sinister "selfservice" in which deputies conspire to provide themselves economic benefits through legislation they pass without effective outside controls. ${ }^{48}$ 
There are, of course, various arguments pro and con regarding fulltime professional status and part-time status for Land deputies. For the part-time option it can be argued that the work of the Land parliaments is fundamentally different from the federal parliament, that they do not have the powers and authority of the Bundestag and are not, therefore, the center of attention. Land deputies should be "closer to the people" and need to maintain close contact through an occupation. Being a professional politician at the Land level is too small a base for a deputy whose roots are only local, and clinging to office creates resentment in the electorate. Some critics readily admit that the deputies work long hours, but they counter that much of that work is "busy work" in parliament and, especially, in the districts designed to justify their salaries. The parliamentary example usually chosen is the large number of "kleine Anfragen," or written questions, that are said to have the effect mostly of tying up the ministerial bureaucracy with unnecessary and picky questions. There are, of course, many examples taken from district work, suggesting that the deputies could do a lot less. The critics are not impressed by the many hours put into party activities by deputies, nor do they consider local office holding an excuse for the burdens of Land office. ${ }^{49}$

While even some deputies agree to some extent with some of these criticisms ${ }^{50}$ they and others would also point to the importance of the parliament primarily as an instrument of control rather than of law making and the need to acquire expertise through legislative experience to exercise this control effectively. They would note the necessity of spending as much time in the district as possible in order to maintain close contacts with citizens, serve as ombudsmen, and retain or gain crucial popular support for the next election, and they would rebut strongly the argument that only part-time politicians with normal occupations are close to the people. ${ }^{51}$ They would cite the importance of maintaining party support for renomination and for connecting the extra-parliamentary party and the party group in parliament. And they would certainly argue that local government office holding is an important source of political information and experience as well as an important political base. All of these functions also serve an important "transmission belt" function for the citizenry, and, in spite of Politikverdrossenheit, many citizens take it for granted that "their" deputy will hear their concerns and, to the extent possible, go to bat for them. In other words, there is an argument to be made for the quality of democracy in any discussion of these functions. ${ }^{52}$ As we have seen above, it can also be argued that Land deputies, even if the sixtyhour week they claim to work on average is somewhat exaggerated, have 
too much to do to serve part-time. This is especially true in the larger Länder. The growth of the public sector and the need for deputies to serve as ombudsmen impose time demands on most deputies that exceed parttime capabilities. ${ }^{53}$ It is precisely the alleged decline of the Land parliaments that requires professionals to prevent even further losses; according to this view, part-time status would reduce the parliamentary meeting time and therefore the control of the government. It would also mean less time spent on service functions for constituents. Some also insist that if deputies are not provided a decent salary, they will become more subject to the influence of lobbyists. One might add that without a decent salary, many potential candidates would also be discouraged from running for office, especially if legislative service takes too much time away from the occupation on which the person relies for an income. A further argument notes that the role of the bureaucracy is likely to increase under part-time deputies. There are also incompatibility rules for various public employees which would make it impossible for the many civil servants who are deputies - including many teachers and some university employees - to serve on a part-time basis. ${ }^{54}$ Many Green deputies have no other employment, ${ }^{55}$ and some deputies in the East are otherwise unemployed. Additional arguments, also common in the United States would include the need for legislative expertise in many fields that can be gained only through experience and the time spent in leadership positions, through service in committees, and participation in other meetings. American data also suggest that deputies in the more professional and full-time legislatures spend more time with their constituents. ${ }^{56}$

One observer has suggested that the belief that part-time deputies would be more broadly representative of the general population is based on a "thinking error" (Denkfehler). He points out that the Land parliament, like other democratic parliaments, is not designed to represent all social and economic groups. The office of a Land deputy has developed into a full-time position not unlike other positions, with various opportunities for advancement, recognition, etc. What the deputies did before in an earlier occupation is much less important than the political skills and effectiveness of the deputy in office. ${ }^{57}$

\section{Conclusion}

Like their counterparts in other countries, parliamentary deputies in Germany - whether at the federal or Land level - are not a representative 
sample of occupation, education, income, gender, and other characterstics; however, the proportions of women in German legislative bodies have increased significantly in all party groups in recent decades, especially with the advent of the Greens in 1979. In a politically more relevant sense, the deputies are representative of the broad currents of political views in the society, from the leftist PDS in the East and Greens in the West to the rightist Republikaner in the West and DVU in East and West. The vast majority of deputies, however, represent the center left SPD or the center right CDU (in Bavaria, the CSU). The proportional electoral system is a crucial factor, of course, in promoting this kind of political representation.

Even though it is often argued that the powers of the Land parliaments have declined over the decades, the Land legislatures do retain important, if limited, powers in certain areas such as education and culture, local government, law and order, and internal organization. And while their law making function may have declined, the deputies are still actively involved in committee meetings and party work groups associated with the parliament, in a variety of service and ombudsman functions in the home district, in political party activities, and, in most cases, in local government office holding. Studies suggest that the deputies work on average about sixty hours per week, excluding any hours they may have worked in their regular occupations as lawyers, businessmen, etc. American state legislators are also active in legislative and district work, but relatively few of them would have the added burden of political party work, and none of them would hold one or even two time-consuming local government offices.

Salaries and benefits for the Land deputies are relatively generous, especially if compared to the typical American state legislator. Only the legislators in the six or seven highest-paying American states are in a roughly equivalent situation. The benefits that German politicians take for granted that would undoubtedly raise the most questions in the United States are the transitional payments received when the deputy leaves office for almost any reason and the retirement benefits received after a relatively short period of time in office. Whether the deputies are overpaid, given the decline of legislative powers in recent decades, is a controversial question. On the one hand, it seems clear that they work long hours. The question some critics raise is whether all the work in which legislators engage is really productive or necessary. In response, deputies would point to their time-consuming work in various kinds of activities related to legislative and control functions, and to the importance of the linkage function between the population on the one hand and the Land government and administration on the other hand. 
The discussion above also relates to the question of whether the deputies should or could be part-time. This debate has to do not only with assessments of the work load of the deputies and their salary and benefits, but also with attitudes concerning the political system in general and the "political class" in particular. As in the United States, ${ }^{58}$ these attitudes are often quite negative. ${ }^{59}$ For those who are contemptuous of politicians, it is doubtful that they could accept the very notion of full-time, reasonably well-paid "professional" politicians at the Land level. ${ }^{60}$ Certainly it can be argued that the salary and benefits for some legislators are overly generous, but it is less clear that they are excessive for the majority of deputies.

\section{Notes}

1 Werner J. Patzelt, "Deutschlands Abgeordnete: Profil eines Berufstands, der weit besser ist als sein Ruf," Zeitschrift für Parlamentsfragen 27, no. 3 (1996), pp. 462-502.

2 Data provided to the author by Werner Patzelt.

3 Rolf Paprotny, Der Alltag der niedersächsischen Landtagsabgeordneten (Hannover: Niedersächsische Landeszentrale für politische Bildung, 1995), Ch. 2.

4 Ibid., p. 27.

5 Ibid., pp. 24-25.

6 Werner J. Patzelt, Abgeordnete undRepräsentation: Amtsverständnis und Wahlkreisarbeit (Passau: Wissenschaftsverlag, 1993) and Abgeordnete und ihr Beruf: Interviews, Umfragen, Analysen (Berlin: Akadamie Verlag, 1995).

7 Patzelt, Abgeordnete und Repräsentation, pp. 314-315, 451.

8 Patzelt, "Deutschlands Abgeordnete," pp. 462-502

9 Ibid., pp. 470-471, 480.

10 Paprotny, Der Alltag, pp. 46-61; Patzelt, Abgeordnete und ihr Beruf, pp. 56-59.

11 Alan Rosenthal, The Decline of Representative Democracy: Process, Participation, and Power in State Legislatures (Washington, DC: CQ Press, 1998), p. 69.

12 Patzelt, "Deutschlands Abgeordnete," p. 477.

13 Paprotny, Der Alltag, pp. 61-64; Patzelt, Abgeordnete und Repräsentation, part 3, and Abgeordnete und ihr Beruf, pp. 94-112. Of course not all Land deputies are elected in districts; up to one-half are elected over lists in the "mixed" district-list proportional representation system. But even most list candidates maintain close ties to their home towns, in order to secure renomination by the party and perhaps to gain the district-seat nomination in the future. Some deputies, however, make a clear distinction between deputies elected by district and list. One even told the author that "a respectable Emslander does not enter parliament over the list."

14 Many American state legislators, especially those with some staff support, 
report that the most important part of their job is the service function they perform. Rosenthal, The Decline, p. 16.

15 Patzelt, Abgeordnete und Repräsentation, p. 136.

16 Werner Patzelt and Roland Schirmer, "Parlamentarismusgründung in den neuen Bundesländern," Aus Politik und Zeitgeschichte B27/96 (28 June 1996), pp. 23-24.

17 Paprotny, Der Alltag, p. 63.

18 Ibid., pp. 68-70.

19 Patzelt, "Deutschlands Abgeordnete," p. 469.

20 Werner Patzelt, "Was tun die Abgeordnete?," in Die Abgeordneten: Stellung, Aufgaben und Selbstverständnis in der parlamentarischen Demokratie, edited by Heinrich Oberreuter (Tutzing: Akademie für politische Bildung, 1996), pp. 25-26. The data are no better for federal parliament members. The same poll showed only 11 percent knew their federal deputy has office hours in the district, and only 6 percent knew that he/she talks to regular citizens (p. 25). Yet Dietrich Herzog et al. found that members of the federal parliament maintained close contacts to their districts, especially with individual citizens and via their district office hours! Abgeordnete und Bürger: Ergebnisse einer Befragung der Mitglieder des 11. Deutschen Bundestages aund der Bevölkerung (Opladen: Westdeutscher Verlag, 1990), pp. 20-21.

21 Patzelt, "Deutschlands Abgeordnete," pp. 497-498.

22 Paprotny, Der Alltag, pp. 73-74; for a more thorough discussion of the Land deputy and the role of the party, see Patzelt, Abgeordnete und ihr Beruf, pp. 140156.

23 Rosenthal, The Decline, p. 61.

24 BVerfGE 40, 296.

25 Herbert Schneider, “Zum Abgeordnetenbild in den Landtagen," Aus Politik und Zeitgeschichte, B5/89 (27 January 1989), p. 6. But for an argument that the decision of the Court was misunderstood, see the comments of one of the judges, Willi Geiger, in Zeitschrift für Parlamentsfragen (1978), p. 528.

26 For critical comments, see Hans Herbert von Arnim, Der Staat als Beute (München: Knaur, 1993), pp. 21-23; a lengthy discussion of the Court's decision can be found in Hans H. Klein, "Diäten-Urteil und Diäten-Streit: Legendenbildung im Verfassungsrecht," in Planung-Recht-Rechtschutz: Festschrift für Willi Blümel, edited by Klaus Grupp (Berlin: Duncker \& Humblot, 1999), pp. 225-257.

27 BVerfGE 76, 256.

28 Hans Herbert von Arnim, Die Partei, der Abgeordnete und das Geld (München: Knauer, 1996), pp. 202-203.

29 See www.hamburg.de/StadtPol/Brgschft.

30 For a table showing the base salaries of federal and Land deputies in the mid1990s, von Arnim, Die Partei, p. 218.

31 Ibid., pp. 246-247. 
32 Ibid., pp. 250-251.

33 Ibid., pp. 266-268.

34 Ibid., pp. 277-286.

35 Ibid., pp. 288-290.

36 Ibid., pp. 298-304.

37 Several books by Hans Herbert von Arnim have focused on a variety of abuses and even scandals in compensation packages in several Länder in the past decade. See, for example, Der Staat als Beute, Staat ohne Diener, or, for a book about federal office holders, Der Staat sind wir!, all published by Knaur, 1993 and 1995.

38 Frankfurter Allgemeine Zeitung (5 October 1996), p. 4.

39 Legislators in California receive $\$ 99,000$ as of January 1999 , whereas legislators in New York and Pennslyvania receive $\$ 57,000-58,000$. California legislators probably receive more in salary than any of their German counterparts, but the latter also receive generous benefits such as retirement payments which a popular referendum has denied California legislators.

40 Rosenthal, The Decline, pp. 63-65.

41 Von Arnim, Die Partei, pp. 312-317.

42 Patzelt, "Deutschlands Abgeordnete," p. 476.

43 Not, as in the inaccurate translation by H. H. Gerth and C. Wright Mills, From Max Weber: Essays in Sociology (New York: Oxford University Press, 1946), only the two types of "vocational" and "occasional" politicians. See Arthur B. Gunlicks, "Max Weber's Typology of Politicians: A Reexamination," The Journal of Politics 40, no. 2 (May 1978), pp. 498-509.

44 Keith E. Hamm and Gary F. Moncrief, "Legislative Politics in the States," in Politics in the American States, edited by Virginia Gray, Russell L. Hanson, and Herbert Jacob (7th edn; Washington, DC: CQ Press, 1999), pp. 145-146.

45 Some legislators refuse to give their occupations as "legislator," even when it is obvious that they are. See Rosenthal, The Decline, p. 57.

46 Peter Raschke and Jens Kalke found that the deputies in Hamburg are generally as engaged in parliamentary activities as most other Land deputies in Germany and argue that they deserve professional status. See their article, "Quantative Analyse parlamentaischer Tätigkeiten der Landtage," Zeitschrift für Parlamentsfragen 25, no. 1 (January 1994), pp. 32-60.

47 Manfred Friedrich, Der Landtag als Berufsparlament? (Karl-Bräuer-Institut des Bundes der Steuerzahler, 1977), p. 54.

48 Hans Herbert von Arnim is the most severe and best-known critic who has revealed a number of scandals involving compensation schemes for Land parliamentary deputies. See, for example, Der Staat als Beute and Staat ohne Diener.

49 For a discussion of some of these arguments, see von Arnim, Die Partei, pp. 227-237.

50 Based on several interviews with deputies from Lower Saxony in autumn 1996. 
51 Schneider, "Zum Abgeordnetenbild," p. 13; Patzelt, Abgeordnete und Repräsentation, Teil 3.

52 See also Schneider, “Zum Abgeordnetenbild,” p. 13.

53 Herbert Schneider, Länderparlamentarismus in der Bundesrepublik (Opladen: Leske \& Budrich, 1979), p. 119.

54 Friedrich, Das Landtag als Berufsparlament? pp. 13-15; Schneider, Länderparlamentarismus, pp. 116-117; Schneider, “Zum Abgeordnetenbild,” pp. 3, 13.

55 Schneider, Zum Abgeordnetenbild," n. 59, p. 15.

56 In the declining number of American states with "citizen legislatures," some delegates report that they do not spend much time with constituents when parliament is not in session. Rosenthal, The Decline, p. 15.

57 Hans Meyer, "Was können und was sollen die Landesparlamente leisten?," in Landesparlamente und Föderalismus: Hat das parlamentarische System in den Bundesländern eine Zukunft?, edited by Franz Gress (Wiesbaden: Hessischer Landtag, 1990), pp. 56-57.

58 Rosenthal, The Decline, pp. 67-71.

59 Patzelt, Abgeordnete und ihr Beruf, pp. 198-206.

60 As indicated above for American legislators (n. 45), many German politicians are reluctant to admit they are professional politicians, even though 90 percent believe that serving in parliament is a career. See Patzelt, "Deutschlands Abgeordnete," p. 467. 